\title{
Characterization of Bacillus Isolates from the Rhizosphere of Tomato Suppressing Fusarium Wilt Disease
}

\author{
M. KAMALI ${ }^{1}$, J. AHMADI ${ }^{1}$, S. NAEIMI ${ }^{2}$ and D. GUO ${ }^{3}$ \\ ${ }^{1}$ Department of Genetics and Plant Breeding, Imam Khomeini International University, Qazvin, Iran \\ ${ }^{2}$ Biological Control Research Department, Iranian Research Institute of Plant Protection, \\ Agricultural Research Education and Extension Organization (AREEO), Tehran, Iran \\ ${ }^{3}$ School of Life Sciences, Chinese University of Hong Kong, Hong Kong
}

(Received: 25 September 2018; accepted: 17 December 2018)

\begin{abstract}
Fusarium wilt of tomato is one of the most prevalent and economically important diseases of tomato worldwide especially in tropical regions. The aims of the present study were to isolate and characterize Bacillus bacteria from tomato rhizospheric soil of various regions in Iran and determine the isolates that exhibit high levels of antagonistic efficiency against tomato Fusarium wilt pathogen, Fusarium oxysporum $\mathrm{f}$. sp. lycopersici $(\mathrm{Fol})$ and growth promotion activity. In this study, 303 Bacillus isolates were obtained from tomato rhizospheric soil. Dual culture and volatile metabolite tests were used to screen for antagonism of Bacillus isolates against Fol. Among them, 20 isolates were found to inhibit pathogen growth by $67.77 \%$ and $33.33 \%$ in dual culture and volatile metabolite tests, respectively. Based on the results of physiological tests and 16S rRNA and gyrA gene sequence analysis of 20 effective isolates, 11, seven and two isolates were identified as B. subtilis, B. velezensis and B. cereus, respectively. The results of greenhouse assessment showed that KR1-2, KR2-7 and A2-9 isolates which were characterized as Bacillus subtilis, reduced the disease index to $16.67 \%$ and promoted the plant growth by $80 \%$. These isolates may serve as potential promising biocontrol agents against Fusarium wilt of tomato.
\end{abstract}

Keywords: Fusarium wilt, tomato, Bacillus, antagonism, growth promotion, biocontrol agents.

Tomato (Solanum lycopersicum) is one of the most consumed vegetables and the seventh most important crop in the world because the worldwide production of tomato reached almost 177 million tons in 2016 (FAOSTAT, http://www.fao.org/faostat/en/\#data/QC). The Asian countries dominate global tomato market among which Iran ranks $6^{\text {th }}$, producing 37 tons per hectare (Bergougnoux, 2014). Many constrains reduce the productivity and quality of tomato, among which diseases, especially fungal diseases play a remarkable role. Tomato Fusarium wilt, caused by a soil-born fungal pathogen, Fusarium oxysporum f. sp. lycopersici $(\mathrm{Fol})$, is one of the economically important fungal diseases that results in a massive loss in production of both field and greenhouse tomatoes worldwide (Agrios, 2005). Its occurrence has been reported in 32 countries especially in countries with warm and humid climate such as United States, Australia, Great Britain, Netherlands, Brazil, Mexico, Morocco, Israel, Iraq (Mui-Yun, 2003) and Iran (Amini, 2009). 
This pathogen attacks the host by destroying the root tissue. It colonizes in the plant xylem, blocks the vascular system and eventually prevents water and nutrients from being transferred to the rest parts of plant host. It causes wilting, discoloration, and finally death of the plant. This pathogen lives as saprophytes in the soil up to ten years (Burgess et al., 2008).

The emergence of new pathogenic isolates and rising threat of fungal plant diseases have led to indiscriminated use of synthetic fungicides that aim at suppressing fungal pathogens and achieving the maximum crop production, which causes serious environmental and health problems. According to the report of the International Labor Organization (ILO) in 2017, a large number of agricultural workers die every year as a result of pesticide poisoning. Focusing more attention on finding environmentally-friendly and food-hygienically-safe alternatives to chemical fungicides for controlling plant pathogens is one of the important aims for many disease control programmes worldwide (Cawoy et al., 2011).

Biological control is a promising alternative to agrochemicals. Although numerous bacteria and fungi with considerable antagonism potential against soil-borne pathogens have been identified, few of them have been commercialized as biocontrol products (Meyer and Roberts, 2002). The majority of commercialized products are bacteria-based biopesticides and about half of them are Bacillus-based products because this bacterial genus retains several valuable traits (Cawoy et al., 2011). Bacillus spp. form dormant spores that are resistant to extreme $\mathrm{pH}$ and temperature and thus can be easily formulated and stored (Stein, 2005). These bacteria are compatible with osmotic conditions. Besides, they colonize root surface, promote plant growth (Turner and Backman, 1991; Cawoy et al., 2011) and protect the plant against pathogen attack using a complex modes of action (Raupach and Kloepper, 1998; Shoda, 2000; Romero et al., 2004). Therefore, the development and utilization of biocontrol products based on these bacteria and or their metabolites are considered as alternative or complimentary methods for chemical control of plant diseases.

Many experimental studies have been done to investigate the biocontrol efficiency of Bacillus species against Fusarium wilt of tomato. The biocontrol effect of four Bacillus species including B. amyloliquefaciens, B. cereus, B. pumilus and B. subtilis were examined against $\mathrm{Fol}$. The results of in vivo experiments revealed that the tomato plants treated with $B$. cereus represented the least disease incidence $(18.75 \%)$ and highest percent disease control (81.2\%) (Ajilogba et al., 2013). Treated tomato seeds with B. amyloliquefaciens (FZB24) resulted in induced-defense enzyme activities and reduced disease incidence (Elanchizhiyan et al., 2018).

Apart from the biocontrol efficiency of Bacillus species, these bacteria also have a plant growth promotion effect (Shafi et al., 2017). The inoculation of spores or cell suspension of $B$. subtilis OTPB1 in tomato seeds significantly increased seedling vigor, shoot and root growth and leaf area of tomato under greenhouse conditions (Chowdappa et al., 2013). Qiao et al. (2017) added the cell suspension of B. subtilis PTS-394 to pot soil of tomato and observed an increase of $8.90 \%$ and $18.30 \%$ in plant height and root weight, respectively, compared with untreated control plants. Spraying both sides of watermelon leaves with cell suspension of B. amyloliquefaciens strain 54 significantly increased the shoot length of bacterial-treated plants because of enhancing the content of available nitrogen $(\mathrm{N})$, phosphorus $(\mathrm{P})$, potassium $(\mathrm{K})$ in soil and leaf chlorophyll (Jiang et al., 2015).

In the present study, Bacillus bacteria were isolated from tomato rhizospheric soil of various regions across Iran. They were evaluated based on growth promotion potential and 
antagonistic activity against Fusarium oxysporum f. sp. lycopersici, in order to determine the Bacillus bacteria that exhibit high levels of antagonistic and growth promotion activities.

\section{Materials and Methods}

\section{Fungal pathogen}

Fusarium oxysporum f. sp. lycopersici (Fol) strain Fo-To-S-V-1 was obtained from the Iranian Research Institute of Plant Protection. It was cultivated on potato dextrose agar (PDA) at $27^{\circ} \mathrm{C}$. The fungal pathogen was sub-cultured onto a fresh PDA plate for further tests.

\section{Isolation of Bacilli}

Tomato rhizosphere soil samples were collected from fields in Golestan, Alborz and Khorasan-Razavi provinces of Iran. Plants in each field were randomly selected, uprooted and $20 \mathrm{~g}$ of rhizosphere soil closely adhering to root of each plant was harvested. All the rhizosphere soil samples from each field were pooled together to make an admixture sample. Each composite soil sample was placed in the sterile plastic bag, maintained on ice, transferred to the laboratory and stored at $4{ }^{\circ} \mathrm{C}$ for further experiments. Soil suspensions were obtained by mixing $10 \mathrm{~g}$ of each soil sample in $90 \mathrm{~mL}$ sterile water for $30 \mathrm{~min}$ at 150 rev $\min ^{-1}$ on a rotary shaker. Each suspension was diluted from $10^{-1}$ to $10^{-6}$ and heated in a water bath at $80^{\circ} \mathrm{C}$ for 10 minutes. $200 \mu 1$ of each dilution was plated onto nutrient agar medium (Shanmugam et al., 2011).

After incubating at $27^{\circ} \mathrm{C}$ for three days, numerous single colonies appeared and most of them belonged to Bacillus genus according to Bergey's Manual of Systematic Bacteriology (Holt et al., 1994). Each Bacillus colony was maintained as a pure culture on a nutrient agar (NA, Merck, Germany; $0.3 \%$ beef extract, $0.5 \%$ peptone and $1.5 \%$ agar) plate with periodic transfer to fresh medium. Besides, they were kept for long-term storage at $-80^{\circ} \mathrm{C}$ in lysogeny broth (LB, Merck, Germany) with $20 \%$ glycerol (v/v).

In vitro screen for antagonistic activity

All of the obtained isolates were evaluated for antagonistic ability against Fol using dual culture and volatile metabolites assays.

\section{Dual culture}

In the dual culture test, each bacterial isolate was cultured at a distance of $3 \mathrm{~cm}$ from a $5 \mathrm{~mm}$ diameter disc of $\mathrm{Fol}$ fresh culture in $9 \mathrm{~cm}$ PDA plates. The control plates were inoculated only with the fungal pathogen. Plates were incubated at $27^{\circ} \mathrm{C}$. The fungal growth was daily checked by measuring the diameter of the colony for a period of three days. The percentage of fungal growth inhibition (PFGI) was calculated by using the formula below, where, $R_{1}$ is the maximum radius of the growth fungal colony in control plate and $R_{2}$ is the radius of the fungal colony that grew in the presence of bacteria (Riungu et al., 2008): 


\section{Volatile metabolite test}

In the volatile metabolites assay, each bacterial isolate was inoculated at the center of a plate containing nutrient agar and incubated at $27^{\circ} \mathrm{C}$ for $24 \mathrm{~h}$. Then, $5 \mathrm{~mm}$ disc of the actively growing culture of the fungal pathogen was placed at the center of a plate containing PDA, inverted over the bacterial culture. Two plates were sealed together with Parafilm ${ }^{\circledR} \mathrm{M}$ and further incubated at $27^{\circ} \mathrm{C}$. The control sets did not contain the bacteria (Fiddaman and Rossall, 1993). The fungal growth was daily checked by measuring the diameter of the colony for a period of three days. The percentage of fungal growth inhibition was obtained using the formula as described earlier.

\section{Physiological and molecular characterization of Bacilli}

Bacillus isolates showing a broad spectrum of antagonistic activity were subjected to further identification according to Bergey's Manual of Systematic Bacteriology (Holt et al., 1994) and sequence analysis of the 16S rRNA and gyrA genes.

For physiological characterization, the gram reaction, motility, growth at $45{ }^{\circ} \mathrm{C}$, growth in $7 \% \mathrm{NaCl}$, utilization of citrate, anaerobic growth in glucose broth, acid and gas production from carbohydrates and starch hydrolysis characteristic of Bacillus isolates were tested following standard procedures (Holt et al., 1994).

For molecular characterization, genomic DNA of Bacillus isolates was extracted from $12 \mathrm{~h}$ old liquid cultures of bacterial isolates grown in Lysogeny Broth medium and prepared based on the standard protocol for bacterial genomic DNA preparations (Jasra, 2004).

The amplification of $16 \mathrm{~S}$ rRNA gene was carried out using a universal primer set consisting of $27 \mathrm{~F}$ (5' $5^{\prime}$-AGAGTTTGATCMTGGCTCAG-3'), 1492 R (5' -TACGGYTACCTTGTTACGACTT-3') (Turner et al., 1999). The PCR reaction was performed according to the thermocycler protocol which included an initial denaturation at $95^{\circ} \mathrm{C}$ for 3 min followed by 30 cycles of denaturation at $95^{\circ} \mathrm{C}$ for $1 \mathrm{~min}$, annealing at $46^{\circ} \mathrm{C}$ for $30 \mathrm{~s}$, and extension at $72{ }^{\circ} \mathrm{C}$ for $1 \mathrm{~min}$, and a final extension at $72{ }^{\circ} \mathrm{C}$ for $10 \mathrm{~min}$ (Li et al., 2012).

A primer set consisting of p-gyrA-f (5'-CAGTCAGGAAATGCGTACGTCCTT-3'), p-gyrA-r (5' -CAAGGTAATGCTCCAGGCATTGCT-3') (Roberts et al., 1994) was used to amplify the gyrA gene. The PCR reaction was performed according to the thermocycler protocol which included an initial denaturation at $95^{\circ} \mathrm{C}$ for 3 min followed by 30 cycles of denaturation at $95{ }^{\circ} \mathrm{C}$ for $1 \mathrm{~min}$, annealing at $52{ }^{\circ} \mathrm{C}$ for $30 \mathrm{~s}$, and extension at $72{ }^{\circ} \mathrm{C}$ for $1 \mathrm{~min}$, and a final extension at $72{ }^{\circ} \mathrm{C}$ for $10 \mathrm{~min}$ ( $\mathrm{Li}$ et al., 2012).

The PCR products were sequenced by the Beijing Genomics Institute (BGI). The $16 \mathrm{~S}$ rRNA and gyrA gene sequences of the studied bacterial isolates were BLASTed against with known sequences in the NCBI GenBank and the phylogenetic tree was constructed using the maximum likelihood method of MEGA 7.0.26 software (Kumar et al., 2016).

\section{Preparing inocula for in vivo assessment}

The bacterial isolates that strongly inhibited the growth of the fungal pathogen in vitro, were grown separately in nutrient broth at $27^{\circ} \mathrm{C}$ for $48 \mathrm{~h}$ under constant shaking $(150 \mathrm{rpm})$ to obtain a final concentration of $10^{8} \mathrm{CFU} \mathrm{ml}^{-1}$ (Chen et al., 2013). 
In order to prepare the pathogen inoculum, corn seeds were washed and soaked in tap water for $24 \mathrm{~h}$ in $2 \mathrm{~L}$ Erlenmeyer flasks. After draining off the excess water, the flasks were filled with corn seeds to one-third and autoclaved twice in two consecutive days. Six $5 \mathrm{~mm}$ diameter disks from seven-day-old PDA culture of Fol were cultured on sterilized corn seeds in each flask (Leslie et al., 2006). The inoculated flasks were maintained at $27^{\circ} \mathrm{C}$ for three weeks. In order to prepare the inoculated soil for in vivo assessment, $5 \mathrm{~g}$ of infected corn seeds were mixed with $1 \mathrm{~kg}$ of sterilized mixture consist of garden soil, sand and fertilizer $(2: 1: 1$ at $\mathrm{w} / \mathrm{w} / \mathrm{w})$.

\section{Assessment of bacterial isolates against $\mathrm{F}$. oxysporum in greenhouse}

Tomato (Solanum lycopersicum) cv. Falat seeds were planted in nursery soil in seedling trays and maintained at $30{ }^{\circ} \mathrm{C}$ in a greenhouse with relative humidity between $40 \%$ to $50 \%$ for six weeks. The seedlings were transplanted to pots containing $3 \mathrm{~kg}$ of pre-treated soil with infected corn seeds and bacterial suspensions were soil drenched $(100 \mathrm{ml} / \mathrm{pot})$. The same concentration of bacterial suspensions was applied 10 days later by soil drenching. The pots in which no bacteria but the pathogen was applied and the pots without any treatment were considered as infected and non-infected control, respectively. Forty-five days after inoculating the pathogen, disease severity was recorded based on a $0-4$ scale in which $0=$ no wilt symptoms, $1=$ wilt symptoms on $1-25 \%$ of the leaves, $2=$ wilt symptoms on $26-50 \%$ of the leaves, $3=$ wilt symptoms on $51-75 \%$ of the leaves and $4=$ wilt symptoms on more than $76 \%$ of the leaves (Chen et al., 2013).

The disease index and biocontrol effect were calculated according to the following formula (Chen et al., 2010):

Biocontrol efficacy $(\%)=\frac{\text { disease index of pathogen control }- \text { disease index of bacteria treatment }}{\text { disease index of pathogen control }} \times 100$

In vivo experiment was repeated twice.

\section{Evaluation plant growth promotion activity of Bacilli}

The bacterial isolates that strongly inhibited the growth of fungal pathogen in vitro, were selected for assessing their plant growth promotion activity in presence of pathogen. In doing so, the height, shoot and root dry weight of plants treated with bacterial isolates and the pathogen simultaneously were compared with those of untreated (non-infected) and the pathogen treated (infected) control plants. At the end of the experiment, the tomato plants were cautiously uprooted and washed off the adhering soil under running tap water. The shoots and roots were separated and shoot height was measured. The dry weight of shoot and root were determined after drying shoots and roots in an oven at $70{ }^{\circ} \mathrm{C}$ for three days.

\section{Statistical analysis}

The variance analysis and comparison of mean test were done using SAS 9.3 software. A completely randomized design and randomized complete block design with three 
replications were used for the in vitro and in vivo experiments, respectively. The significant differences between treatments were evaluated by Fisher's least significant difference (LSD) test and $P \leq 0.05$ was considered as critical differences.

\section{Results}

Isolation, screen, and selection of Bacillus isolates with antagonistic activity

Totally, 303 Bacillus isolates were obtained from tomato rhizospheric soils of three provinces. Out of these, 108 isolates showed antagonistic activity against Fusarium oxysporum $\mathrm{f}$. sp. lycopersici in dual culture test. Among them, 31 isolates inhibited the fungal mycelial growth more than $50 \%$ in the dual culture test (Table 1, Fig. 1). Besides, these 31
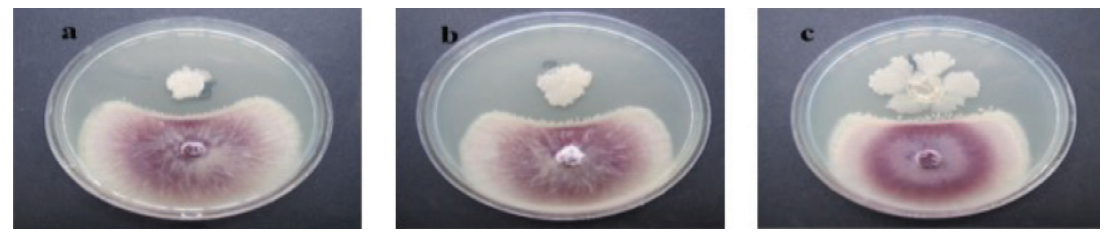

Fig. 1. The growth of Fusarium oxysporum f. sp. lycopersici (Fol) inhibited by Bacillus isolates in dual culture test. Antagonism pattern

a) G1-7 b) KR2-7 and c) A2-19 against Fol

bacterial isolates also controlled the growth of $\mathrm{Fol}$ in the volatile metabolite test, but there was variability among them. KR2-7 was the most effective isolate as $46.67 \%$ inhibition (Table 1). Based on the results of in vitro experiments, 20 Bacillus isolates that inhibited the pathogen growth more than $50 \%$ and $15 \%$ in dual culture and volatile metabolite, respectively, were selected for further study.

\section{Physiological and molecular identification of Bacillus isolates}

Based on physiological tests, 11 out of 20 antagonistic isolates were characterized as Bacillus subtilis and nine remaining isolates, including G1-8, G1-24, G2-21, G2-22, G3-1, G3-3, KR1-23, KR2-5 and A1-34 which belonged to other species of Bacillus (Table 2). Results of 16S rRNA and gyrA sequence analysis confirmed the identification of Bacillus subtilis isolates and G2-22 and A1-34 isolates were identified as Bacillus cereus. Moreover, G1-8, G1-24, G2-21, G3-1, G3-3, KR1-23 and KR2-5 were characterized as Bacillus velezensis. A phylogenetic tree was constructed based on $16 \mathrm{~S}$ rRNA and gyrA sequences (Fig. 2). The 16S RNA sequences of 20 bacterial isolates were deposited in the NCBI GenBank database. 
Table 1

The percentage of Fusarium oxysporum $\mathrm{f}$. sp. lycopersici growth inhibition by Bacillus isolates in dual culture and volatile metabolite tests

\begin{tabular}{|c|c|c|c|}
\hline The source of bacteria & Isolate code & PFGI* in dual culture test & PFGI* in volatile metabolite test \\
\hline \multirow{15}{*}{ Golestan province } & G1-2 & $62.22 \pm 1.11 \mathrm{abcd}$ & $13.34 \pm 1.2 \mathrm{gh}$ \\
\hline & G1-7 & $61.11 \pm 1.2$ abcde & $13.33 \pm 0.69 \mathrm{gh}$ \\
\hline & G1-8 & $64.44 \pm 2.93 \mathrm{abc}$ & $25.56 \pm 1.03 \mathrm{c}$ \\
\hline & G1-11 & $63.33 \pm 5.02 \mathrm{abc}$ & $14.29 \pm 0.57 \mathrm{fg}$ \\
\hline & G1-24 & $63.33 \pm 1.92 \mathrm{abc}$ & $18.88 \pm 1.89 \mathrm{~d}$ \\
\hline & G2-8 & $63.33 \pm 1.9 \mathrm{abc}$ & $5.54 \pm 0.38 \mathrm{jk}$ \\
\hline & $\mathrm{G} 2-21$ & $67.77 \pm 2.22 \mathrm{ab}$ & $18.36 \pm 0.85 \mathrm{de}$ \\
\hline & G2-22 & $67.77 \pm 1.92 \mathrm{ab}$ & $15.08 \pm 0.62 \mathrm{efg}$ \\
\hline & G2-29 & $65.55 \pm 1.1 \mathrm{ab}$ & $18.76 \pm 1.13 \mathrm{~d}$ \\
\hline & G2-38 & $51.11 \pm 2.93 \mathrm{~g}$ & $17.77 \pm 1.11 \mathrm{def}$ \\
\hline & $\mathrm{G} 2-45$ & $66.67 \pm 6.93 \mathrm{ab}$ & $10 \pm 0.76 \mathrm{hi}$ \\
\hline & G3-1 & $67.77 \pm 1.2 \mathrm{a}$ & $15.06 \pm 0.63 \mathrm{efg}$ \\
\hline & G3-2 & $65.55 \pm 4.83 \mathrm{ab}$ & $8.88 \pm 0.98 \mathrm{ij}$ \\
\hline & G3-3 & $67.77 \pm 1.11 \mathrm{ab}$ & $23.33 \pm 1.53 \mathrm{c}$ \\
\hline & G3-11 & $62.22 \pm 1.2 \mathrm{abcd}$ & $16.66 \pm 0$ defg \\
\hline \multirow{8}{*}{ Khorasan Razavi province } & KR1-2 & $61.11 \pm 2.93$ abcde & $26.63 \pm 0.87 \mathrm{c}$ \\
\hline & KR1-23 & $54.44 \pm 2.22 \mathrm{defg}$ & $16.66 \pm 0.19$ defg \\
\hline & KR2-5 & $68.88 \pm 2.93 \mathrm{a}$ & $23.36 \pm 1.96 \mathrm{c}$ \\
\hline & KR2-7 & $64.44 \pm 2.9 \mathrm{abc}$ & $46.67 \pm 1.92 \mathrm{a}$ \\
\hline & KR2-8 & $54.44 \pm 4.44$ defg & $1.1 \pm 0.581$ \\
\hline & KR2-9 & $52.22 \pm 7.28 \mathrm{fg}$ & $2.22 \pm 0.22 \mathrm{kl}$ \\
\hline & KR2-15 & $50.11 \pm 1.25 \mathrm{~g}$ & $32.22 \pm 0.97 b$ \\
\hline & KR3-10 & $51.11 \pm 2.93 \mathrm{~g}$ & $31.11 \pm 0.8 \mathrm{~b}$ \\
\hline \multirow{8}{*}{ Alborz province } & A1-9 & $51.11 \pm 2.8 \mathrm{~g}$ & $17.77 \pm 0.4 \mathrm{def}$ \\
\hline & A1-34 & $53.33 \pm 2.9 \mathrm{efg}$ & $26.67 \pm 1.11 \mathrm{c}$ \\
\hline & A2-4 & $54.44 \pm 3.33 \mathrm{defg}$ & $14.44 \pm 2.11 \mathrm{fg}$ \\
\hline & A2-9 & $52.22 \pm 2.76 \mathrm{fg}$ & $24.44 \pm 1.12 \mathrm{c}$ \\
\hline & A2-20 & $52.22 \pm 2.83 \mathrm{fg}$ & $6.66 \pm 1.87 \mathrm{ij}$ \\
\hline & A2-21 & $56.67 \pm 2.22 \mathrm{cdef}$ & $5.55 \pm 0.96 \mathrm{jk}$ \\
\hline & A2-22 & $54.44 \pm 1.92 \mathrm{defg}$ & $24.44 \pm 0.55 \mathrm{c}$ \\
\hline & A2-25 & $53.35 \pm 1.39 \mathrm{efg}$ & $33.33 \pm 2.98 b$ \\
\hline
\end{tabular}

Each value represents mean \pm standard error from three independent replications. Values with different lowercase letters are significantly different according to LSD test at $\mathrm{P}<0.05$.

*PFGI: The percentage of fungal growth inhibition. 


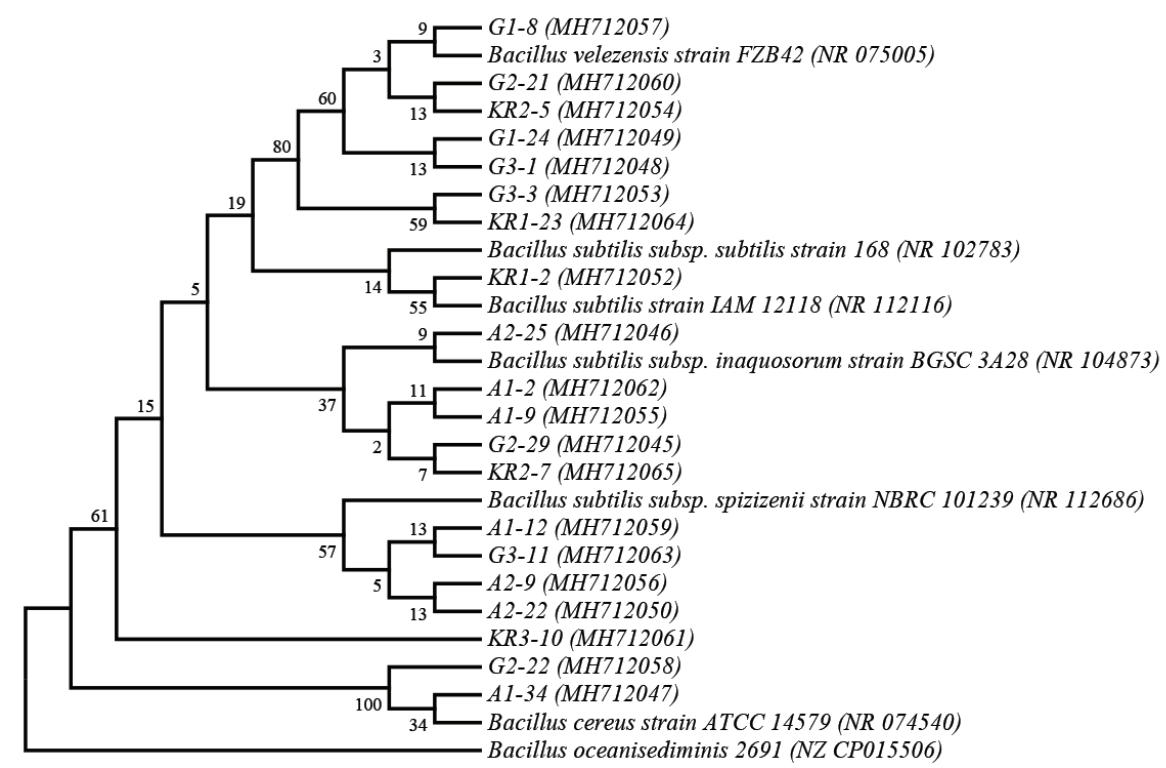

Fig. 2. Phylogenetic trees of 20 Bacillus strains based on 16S rRNA and gyrA gene sequences. Numbers at nodes represent the percentages of occurrence of nodes in 1000 bootstrap trials. The Bacillus oceanisediminis (NZ_CP015506) was served as outgroup

\section{Biocontrol of tomato Fusarium wilt in greenhouse}

The biocontrol efficacy of 20 selected Bacillus isolates was evaluated under greenhouse conditions. After eight weeks of inoculation, the initial symptoms of tomato Fusarium wilt including yellowing and wilting of the lower leaves appeared and then spread to the upper leaves of plants.

According to the results of in vivo biocontrol evaluation (Table 3), the $20 \mathrm{Ba}$ cillus isolates were categorized into three groups including highly effective, effective, and non-effective isolates. The highly effective group consists of three isolates, KR1-2, KR2-7, and A2-9, as they have shown the lowest disease index percentage (16.67\%) without any significant difference from non-infected control and with the highest biocontrol efficiency (80\%). Since the effect of G1-8, G2-21, G3-3, G3-11, KR1-35, KR2-5, KR3-10, A1-34 and A2-22 on suppressing the fungal pathogen invasion was less pronounced than that of the more effective group, we therefore categorized these nine isolates as effective biocontrol Bacillus. The rest of Bacillus isolates, including G1-24, G2-22, G2-29, G3-1, KR1-23, KR2-15, A1-9, A1-12 and A2-25, were considered as non-effective isolates because they did not significantly reduce the disease index percentage in comparison with infected control plants.

\section{Plant growth promotion effect of Bacillus isolates under greenhouse conditions}

The plant growth promotion potential of 20 Bacillus isolates was studied by measuring several growth parameters, i.e. plant height, dry shoot and root weight (Table 4). Twenty isolates were classified into three groups encompassing the highly effective, ef- 


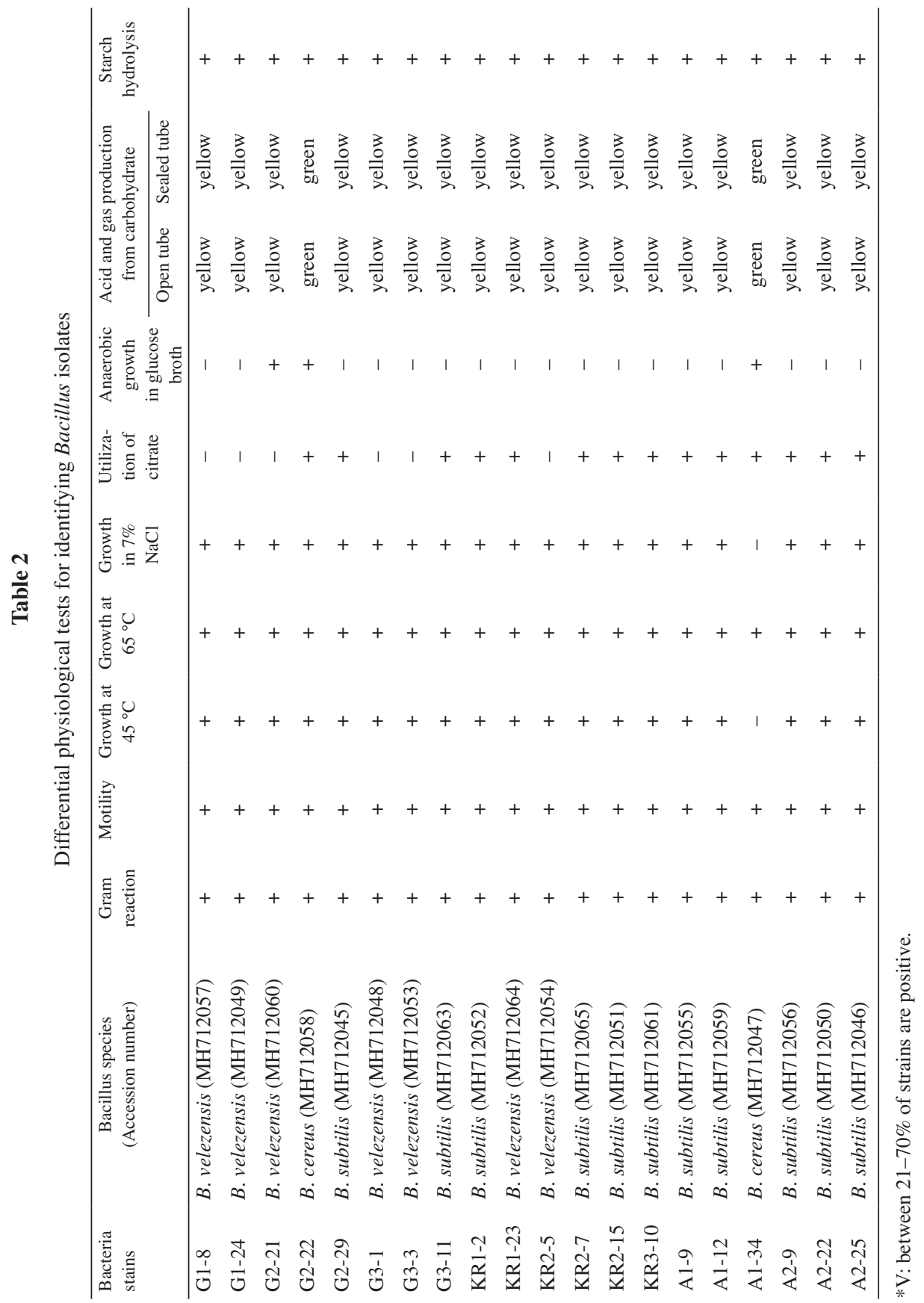


Table 3

The biocontrol effect of 20 selected Bacillus isolates on Fusarium wilt of tomato

\begin{tabular}{lll}
\hline Treatment & Disease index $(\%)$ & Biocontrol efficacy $(\%)$ \\
\hline Infected control & $77.78 \mathrm{a}$ & - \\
Non-infected control & $16.67 \mathrm{e}$ & - \\
G1-8 & $27.78 \mathrm{de}$ & $66.67 \mathrm{ab}$ \\
G1-24 & $66.67 \mathrm{ab}$ & $20 \mathrm{de}$ \\
G2-21 & $27.78 \mathrm{de}$ & $66.67 \mathrm{ab}$ \\
G2-22 & $77.78 \mathrm{a}$ & $6.67 \mathrm{e}$ \\
G2-29 & $55.56 \mathrm{abc}$ & $33.33 \mathrm{cde}$ \\
G3-1 & $72.22 \mathrm{a}$ & $13.33 \mathrm{e}$ \\
G3-3 & $27.78 \mathrm{de}$ & $66.67 \mathrm{ab}$ \\
G3-11 & $22.22 \mathrm{de}$ & $73.33 \mathrm{ab}$ \\
KR1-2 & $16.67 \mathrm{e}$ & $80 \mathrm{a}$ \\
KR1-23 & $61.11 \mathrm{ab}$ & $26.67 \mathrm{de}$ \\
KR2-5 & $22.22 \mathrm{de}$ & $73.33 \mathrm{ab}$ \\
KR2-7 & $80 \mathrm{a}$ \\
KR2-15 & $16.67 \mathrm{e}$ & $33.33 \mathrm{cde}$ \\
KR3-10 & $55.56 \mathrm{abc}$ & $60 \mathrm{abc}$ \\
A1-9 & $33.33 \mathrm{cde}$ & $33.33 \mathrm{cde}$ \\
A1-12 & $55.56 \mathrm{abc}$ & $33.33 \mathrm{cde}$ \\
A1-34 & $55.56 \mathrm{abc}$ & $46.67 \mathrm{bcd}$ \\
A2-9 & $44.44 \mathrm{bcd}$ & $80 \mathrm{a}$ \\
A2-22 & 16.67 & $73.33 \mathrm{ab}$ \\
A2-25 & $22.22 \mathrm{de}$ & $33.33 \mathrm{cde}$ \\
\hline
\end{tabular}

Values with different lowercase letters are significantly different according to the LSD test at $P<0.05$.

fective and non-effective Plant Growth Promoting Rhizobacteria (PGPR). KR1-2, KR2-7 and A2-9 were the highly effective PGPR agents. G2-22, KR1-23, KR2-15, A1-9, A1-12 and A1-34 were categorized as non-effective PGPR agents because the growth parameters of treated plants with these bacterial isolates did not present a significant difference compared to infected control plants. The remaining 8 Bacillus isolates especially G3-3, KR2-5, KR3-10 and A2-22 were grouped as effective PGPR agents because the inoculated plants by these Bacillus isolates showed growth parameters close to those of non-infected control plants (Table 4).

\section{Discussion}

Antagonistic bacteria are widely utilized for biological control of soil-borne phytopathogens to reduce agrochemical consumption, facilitate sustainable agriculture implementation, and promote plant growth. In order to control various fungal phytopathogens within an acceptable level, numerous research attempts using Bacillus spp. as biocontrol 
Table 4

The influence of Bacillus isolates on growth parameters of tomato under greenhouse conditions

\begin{tabular}{|c|c|c|c|c|}
\hline PGPR group & Treatment & Plant height $(\mathrm{cm})$ & Dry shoot weight $(\mathrm{g})$ & Dry root weight $(\mathrm{g})$ \\
\hline- & Infected control & $59.33 \pm 1.2 \mathrm{k}$ & $6.73 \pm 0.88 \mathrm{~h}$ & $4.4 \pm 0.24 \mathrm{kl}$ \\
\hline- & $\begin{array}{l}\text { Non-infected } \\
\text { control }\end{array}$ & $96.67 \pm 2.33 \mathrm{ab}$ & $12.36 \pm 0.33 \mathrm{a}$ & $9.56 \pm 0.26 \mathrm{a}$ \\
\hline \multirow{3}{*}{$\begin{array}{l}\text { Highly } \\
\text { effective } \\
\text { PGPR }\end{array}$} & KR1-2 & $97.33 \pm 2.91 \mathrm{a}$ & $11.8 \pm 0.95 \mathrm{ab}$ & $9 \pm 0.36 \mathrm{ab}$ \\
\hline & KR2-7 & $94 \pm 2.08 \mathrm{abc}$ & $10.8 \pm 0.3 \mathrm{abcd}$ & $8.63 \pm 0.24 \mathrm{abc}$ \\
\hline & A2-9 & $90.33 \pm 1.45$ abcde & $10.16 \pm 0.46 \mathrm{abcd}$ & $8.56 \pm 0.34 \mathrm{abcd}$ \\
\hline \multirow{11}{*}{$\begin{array}{l}\text { Effective } \\
\text { PGPR }\end{array}$} & G1-8 & $87.66 \pm 1.2$ abcdef & $9.06 \pm 0.4 \mathrm{def}$ & $7.26 \pm 0.21 \mathrm{efg}$ \\
\hline & G1-24 & $79.66 \pm 1.2 \mathrm{fghi}$ & $9.26 \pm 0.08 \mathrm{de}$ & $6.03 \pm 0.12$ ghij \\
\hline & G2-21 & $83 \pm 2.08 \mathrm{defg}$ & $8.67 \pm 0.98$ efgh & $7.23 \pm 0.83 \mathrm{efg}$ \\
\hline & G2-29 & $73 \pm 8.19$ ghij & $9.13 \pm 0.24 \mathrm{def}$ & $6.06 \pm 0.14$ ghij \\
\hline & G3-1 & $71.66 \pm 1.2 \mathrm{ij}$ & $9.36 \pm 0.4 \mathrm{de}$ & $5.43 \pm 0.17$ hijk \\
\hline & G3-3 & $82 \pm 1.53$ defgh & $9.76 \pm 1.23 \mathrm{cde}$ & $7.93 \pm 0.67$ bcde \\
\hline & G3-11 & $85.66 \pm 1.2 \mathrm{cdef}$ & $8.93 \pm 0.65 \mathrm{defg}$ & $6.16 \pm 0.72 \mathrm{ghi}$ \\
\hline & KR2-5 & $90.66 \pm 3.38 \mathrm{abcd}$ & $9.26 \pm 1.16 \mathrm{de}$ & $7.6 \pm 0.75 \mathrm{cdef}$ \\
\hline & KR3-10 & $84.66 \pm 2.6 \mathrm{cdef}$ & $11.5 \pm 0.55 \mathrm{ab}$ & $7.96 \pm 0.4$ bcde \\
\hline & A2-22 & $91 \pm 0.58$ abcde & $9.36 \pm 0.72 \mathrm{de}$ & $7.23 \pm 0.14 \mathrm{efg}$ \\
\hline & A2-25 & $79 \pm 2.52$ fghi & $9.9 \pm 0.47$ bcde & $6.23 \pm 0.46 \mathrm{ghi}$ \\
\hline \multirow{6}{*}{$\begin{array}{l}\text { Non-effective } \\
\text { PGPR }\end{array}$} & G2-22 & $72.33 \pm 2.94$ hij & $6.9 \pm 0.47 \mathrm{~h}$ & $5.03 \pm 0.08 \mathrm{ijkl}$ \\
\hline & KR1-23 & $79 \pm 2.31 \mathrm{fghi}$ & $7 \pm 0.11 \mathrm{gh}$ & $4.76 \pm 0.51 \mathrm{jkl}$ \\
\hline & KR2-15 & $66.67 \pm 3.24 \mathrm{jk}$ & $8.26 \pm 1.56$ efgh & $4.96 \pm 1.06 \mathrm{ijkh}$ \\
\hline & A1-9 & $65.33 \pm 3.23 \mathrm{jk}$ & $7.26 \pm 0.14 \mathrm{fgh}$ & $4.1 \pm 0.171$ \\
\hline & A1-12 & $71.66 \pm 6.36 \mathrm{ij}$ & $8.36 \pm 0.72$ efgh & $5.26 \pm 0.18$ hijkl \\
\hline & A1-34 & $80.33 \pm 2.06$ efghi & $8.63 \pm 0.49$ efgh & $5.1 \pm 0.32$ hijkl \\
\hline
\end{tabular}

Values with different letters are significantly different according to the LSD test at $P<0.05$.

agents and biofertilizers have been conducted (Cazorla et al., 2007; Cao et al., 2011; Li et al., 2012; Chen et al., 2013). Identification, screening and eventually selecting the most effective Bacillus isolates which control plant disease and enhance crop yield hold great promise in maintaining the sustainability of agroecosystems.

In this work, 303 Bacillus isolates were screened by dual culture and volatile metabolite tests. Among them, 20 isolates were identified as highly effective Bacillus isolates because they could limit the radial growth of Fol considerably. This antagonistic effect may be attributed to the production of diffusable and antifungal compounds such as cyclic peptides (e.g. iturin) and macrolactones including plipastatins, fengycins and surfactins. (Chaurasia et al., 2005; Cao et al., 2011; Gong et al., 2015).

In case of taxonomy characterization of Bacillus bacteria, sequence analysis of $16 \mathrm{~S}$ rRNA accompanied with one of gyrA, gyr B, polC and $r p r o B$ genes can provide conclusive evidence on phylogenetic relationship of Bacillus spp. (Chun and Bae, 2000). Therefore, the taxonomy of 20 effective biocontrol isolates was characterized by physiological as well as 16S rRNA gene and gyrA gene-based phylogenetic analysis. The results of the physiological tests were in agreement with the results of 16S rRNA gene and gyrA gene sequence analysis. 
In this study, A1-34 belonged to B. cereus species. This isolate was grouped as an effective biocontrol agent because it controlled the Fusarium wilt disease by $44.44 \%$. The biocontrol potential of $B$. cereus can be attributed to the production of plipastatins that prevents phospholipase A2 (PLA2) enzyme released by fungal pathogen. This enzyme plays an important role in hydorylizing lipids and phospholipids of host cell (Kohler et al., 2006). Besides, this species enhances defense related phenolic compounds activities (Shafi et al., 2017). Wang et al. (2014) showed that treatment of loquat fruit with B. cereus AR156 resulted in lower disease incidence due to the enhancement of defense-related activities such as phenylalanine ammonia-lyase, peroxidase and polyphenoloxidase, chitinase, $\beta$-1,3-glucanase, and the stimulated condensing of $\mathrm{H}_{2} \mathrm{O}_{2}$.

According to the results of present study, G1-8, G2-21, G3-3 and KR2-5 were grouped as effective biocontrol agent because they suppressed Fusarium wilt disease between $22 \%$ to $27 \%$. Moreover, G3-3 and KR2-5 were classified as effective PGPR agensts because the growth parameters of treated tomato plants with these isolates were close to the growth parameters of non-infected control plants. These isolate were identified as B. velezensis. Suppressing the phytopathogenic fungi by B. velezensis may be due to the production of diffusable and volatile antifungal compounds. Lim et al. (2017) identified bacillomycin $\mathrm{L}$ and fengycin $\mathrm{A}$ as agar-diffusible antifungal metabolites produced by $B$. velezensis G341. Moreover, they found that this strain produced three volatile compounds including dimethylsulfoxide, 1-butanol, and 3-hydroxy-2-butanone (acetoin) against various phytopathogenic fungi. Moreover, Bacillus strains promoted plant growth by producing phytohormones. $B$. velezensis strain BAC03, enhanced the growth of nine plants including beet, carrot, cucumber, pepper, potato, radish, squash, tomato, and turnip by producing indole-3-acetic acid and ammonia with ACC (1-aminocyclopropane-1-carboxylate) deaminase activity (Meng et al., 2016).

In the present study, KR1-2, KR2-7 and A2-9 isolates characterized as B. subtilis remarkably suppressed $\mathrm{Fol}$ and resulted in the lowest disease index (16.67\%) and highest bicontrol efficacy (80\%). The biocontrol function of B. subtilis encompasses various modes of actions. First, these bacteria induce the systematic resistance in plants (Ongena et al., 2007). Second, they compete for nutrients and ecological niche in rhizosphere environment (Bais et al., 2004). Third, they produce extracellular enzymes such as chinitase and $\beta$-1,3-glucanase (Zhang et al., 2008; Chen et al., 2010), a diverse range of antimicrobial compounds, for instance iturin, surfactin and fengysin (Stein, 2005; Baysal et al., 2013), and siderophores which provides iron for plants and deprives fungal pathogen from Iron (Rana et al., 2011). Forth, B. subtilis strains form biofilm which serves as biobarrier on the root to protect the plant from pathogen infection (Bais et al., 2004; Morikawa et al., 2006). Since $B$. subtilis possesses these beneficial characteristics, numerous studies were performed to identify new $B$. subtilis isolates and evaluate their biocontrol effectiveness against various ranges of plant pathogens. The application of strain APPL-1 of B. subtilis on bean 2 to $120 \mathrm{~h}$ before the inoculation of Uromyces appendiculatus decreased the number of pustules of bean rust by $95 \%$ (Baker et al., 1983). Li et al. (2012) characterized B068150 as B. subtilis with biocontrol effect up to 50.68\% against Fusarium oxysporum f. sp. cucumerinum under greenhouse conditions.

Bacillus subtilis is considered as a plant growth promoting rhizobacteria (PGPR) due to its ability in the production of stimulating phytohormones, i.e. indole acetic acid (IAA), gibberellins, and cytokinins, solubilization and mobilization of phosphate, fixation 
of nitrogen, siderophores production, inhibition of plant ethylene synthesis and induction of plant systemic resistance to pathogens (Gutierrez-Manero et al., 2001; Whipps, 2001; Idris et al., 2007; Richardson et al., 2009). Inoculation of Bacillus subtilis S25 strain on tomato rhizosphere resulted in significant increase in plant growth parameters (Sharma et al., 2015).

This study led to the identification of promising B. subtilis isolates, KR1-2, KR2-7 and A2-9, as potentially effective biocontrol agents. Further investigation is needed to elucidate the underlying mechanisms of their antagonistic effect.

\section{Literature}

Agrios, G. N. (2005): Plant Pathology, 5th ed., Elsevier Academic Press, London, UK, 922 p.

Ajilogba, C. F., Babalola, O. O. and Ahmad, F. (2013): Antagonistic effects of Bacillus species in biocontrol of tomato Fusarium wilt. Studies on Ethno-Medicine 7, 205-216. https://doi.org/10.1080/09735070.2013. 11886462.

Amini, J. (2009): Physiological race of Fusarium oxysporum f. sp. lycopersici in Kurdistan province of Iran and reaction of some tomato cultivars to race 1 of pathogen. Plant Pathol. J. 8, 68-73.

Bais, H. P., Fall, R. and Vivanco, J. M. (2004): Biocontrol of Bacillus subtilis against infection of arabidopsis roots by Pseudomonas syringae is facilitated by biofilm formation and surfactin production. Plant Physiol. 134, 307-319. https://doi.org/10.1104/pp.103.028712.

Baker, C. J., Stavely, J. R., Thomas, C. A., Saser, M. and MacFall, J. S. (1983): Inhibitory effect of Bacillus subtilis on Uromyces phaseoli and on development of rust pustules on bean leaves Phaseolus vulgaris. Phytopathology 73, 1148-1152.

Baysal, O., Lai, D., Xu, H. H., Siragusa, M., Calışkan, M., Carimi, F., Teixeira da Silva, J. A. and Tor, M. (2013): A proteomic approach provides new insights into the control of soil-borne plant pathogens by Bacillus species. PLoS ONE, 8(1), e53182. https://doi.org/10.1371/journal.pone.0053182.

Bergougnoux, V. (2014): The history of tomato: From domestication to biopharming. Biotech. Adv. 32, 170-189. https://doi.org/10.1016/j.biotechadv.2013.11.003.

Burgess, L. W., Knight, T. E., Tesoriero, L. and Phan, H. T. (2008): Diagnostic Manual for Plant Diseases in Vietnam. ACIAR, Canberra, pp. 126-133.

Cao, Y., Zhang, Z., Ling, N., Yuan, Y., Zheng, X., Shen, B. and Shen, Q. (2011): Bacillus subtilis SQR 9 can control Fusarium wilt in cucumber by colonizing plant roots. Biol. Fertil. Soils 47, 495-550. https://doi. org/10.1007/s00374-011-0556-2.

Cawoy, H., Bettiol, W., Fickers, P. and Ongena, M. (2011): Bacillus-based biological control of plant diseases, pesticides in the modern world - Pesticides use and management. In: M. Stoytcheva (ed.): ISBN: 978-953-307-459-7, Tech, http://www.intechopen.com/books/pesticides-in-themodern-world-pesticides-use-and-management/bacillus-based-biological-control-of-plant-diseases.

Cazorla, F. M., Romero, D., Pérez-García, A., Lugtenberg, B. J. J., Vicente, A. D. and Bloemberg, G. (2007): Isolation and characterization of antagonistic Bacillus subtilis strains from the avocado rhizoplane displaying biocontrol activity. J. Appl. Microbiol. 103, 1950-1959. https://doi.org/10.1111/j.13652672.2007.03433.x.

Chaurasia, B., Pandey, A., Palni, L. M., Trivedi, P., Kumar, B. and Colvin, N. (2005): Diffusible and volatile compounds produced by an antagonistic Bacillus subtilis strain cause structural deformations in pathogenic fungi in vitro. Microbiol. Res. 160, 75-81. https://doi.org/10.1016/j.micres.2004.09.013.

Chen, F., Wang, M., Zheng, Y., Luo, J., Yang, X. and Wang, X. (2010): Quantitative changes of plant defense enzymes and phytohormone in biocontrol of cucumber Fusarium wilt by Bacillus subtilis B579. World J. Microbiol. Biotechnol. 26, 675-684. https://doi.org/10.1007/s11274-009-0222-0.

Chen, Y., Yan, F., Chai, Y., Liu, H., Kolter, L., Losick, R. and Guo, J. H. (2013): Biocontrol of tomato wilt disease by Bacillus subtilis isolates from natural environments depends on conserved genes mediating biofilm formation. Environ. Microbiol. 15, 848-864. https://doi.org/10.1111/j.1462-2920.2012.02860.x. 
Chowdappa, P., Kumar, S. M., Lakshmi, M. J. et al. (2013): Growth stimulation and induction of systemic resistance in tomato against early and late blight by Bacillus subtilis OTPB1 or Trichoderma harzianum OTPB3. Biol. Control, 65, 109-117. https://doi.org/10.1016/j.biocontrol.2012.11.009.

Chun, J. and Bae, K. S. (2000): Phylogenetic analysis of Bacillus subtilis and related taxa based on partial gyrA gene sequence. Antonie van Leeuwenhoek, 78, 123-127. https://doi.org/10.1023/A:1026555830014.

Elanchizhiyan, K., Keerthana, U., Nagendran, K., Prabhukarthikeyan, S. R., Prabakar, K., Raguchander, T. and Karthikeyan, G. (2018): Multifaceted benefits of Bacillus amyloliquefaciens strain FBZ24 in the management of wilt disease in tomato caused by Fusarium oxysporum f. sp. lycopersici. Physiol. Mol. Plant Pathol. 103, 92-101.

Fiddaman, P. J. and Rossall, S. (1993): The production of antifungal volatiles by Bacillus subtilis. J. Appl. Bacteriol., 74, 119-126.

Gong, A. D., Li, H. P., Yuan, Q. S., Song, X. S., Yao, W., He, W. J., Zhang, J. B., and Lio, Y. C. (2015): Antagonistic mechanism of iturin A and plipastatin A from Bacillus amyloliquefaciens S76-3 from wheat spikes against Fusarium graminearum. PLoS ONE, 10(2), e0116871. https://doi.org/10.1371/journal. pone.0116871.

Gutierrez-Manero, F. J., Ramos, B., Probanza, A., Mehouachi, J. and Talon, M. (2001): The plant growth promoting rhizobacteria Bacillus pumilus and Bacillus licheniformis produce high amounts of physiologically active gibberelins. Physiol. Plant. 111, 206-211. https://doi.org/10.1034/j.1399-3054.2001.1110211.x.

Holt, J. G., Krieg, N. R., Sneath, P. H. A., Staley, J. T. and Williams, S. T. (1994): Bergey's Manual of Determinative Bacteriology. 9th ed. The Williams and Wilkins Co., Baltimore, 787 p.

Idris, E. E. S., Iglesias, D. J., Talon, M. and Borriss, R. (2007): Tryptophan-dependent production of Indole-3Acetic Acid (IAA) affects level of plant growth promotion by Bacillus amyloliquefaciens FZB42. Mol. Plant Microbe Interact. 20, 619-626.

ILO (2017): Portfolio of policy guidance note on the promotion of decent work in the rural economy: Decent and productive work in agriculture. International Labor Organization, Geneva.

Jasra, O. P. (2004): Preparation of genomic DNA from Bacteria. In: Y. Gupta (ed.): Techniques in Microbiology, 1st ed. Sarup and Sons Publication, India, pp. 25-26.

Jiang, C. H., Wu, F., Yu, Z. Y., Xie, P., Ke, H. J., Li, H. W., Yu, Y. Y. Gupta and Guo, J. H. (2015): Study on screening and antagonistic mechanisms of Bacillus amyloliquefaciens 54 against bacterial fruit blotch (BFB) caused by Acidovorax avenae subsp. citrulli. Microbiol. Res. 170, 95-104. https://doi. org/10.1016/j.micres.2014.08.009.

Kohler, G. A., Brenot, A., Hass-Stapleton, E., Agabian, N., Deva, R. and Nigam, S. (2006): Phospholipase A $_{2}$ and phospholipase B activities in fungi. Biochim. Biophys. Acta 1761, 1391-1399.

Kumar, S., Stecher, G. and Tamura, K. (2016): MEGA7: Molecular evolutionary genetics analysis version 7.0 for bigger datasets. Mol. Biol. Evol. 33, 1870-1874. https://doi.org/10.1093/molbev/msw054.

Leslie, J. F., Summerell, B. A. and Bullock, S. (2006): The Fusarium Laboratory Manual. Blackwell Publishing, Oxford, UK, 388 p.

Li, L., Ma, J., Li, Y., Wang, Z., Gao, T. and Wang, Q. (2012): Screening and partial characterization of Bacillus with potential applications in biocontrol of cucumber Fusarium wilt. Crop Prot. 35, 29-35. https://doi. org/10.1016/j.cropro.2011.12.004.

Lim, S. M., Yoon, M. Y., Choi, G. J., Choi, Y. H., Jang, K. S., Shin, T. S., Park, H. W., Yu, N. H., Ho Kim, Y. H. and Kim, J. C. (2017): Diffusible and volatile antifungal compounds produced by an antagonistic Bacillus velezensis G341 against various phytopathogenic fungi. Plant Pathol. J. 33, 488-498. https://dx.doi. org/10.5423\%2FPPJ.OA.04.2017.0073.

Meng, Q., Jiang, H. and Hao, J. J. (2016): Effects of Bacillus velezensis strain BAC03 in promoting plant growth. Biolog. Control 98, 18-26. https://doi.org/10.1016/j.biocontrol.2016.03.010.

Meyer, S. L. F. and Roberts, D. P. (2002): Combinations of biocontrol agents for management of plant-parasitic nematodes and soil-borne plant-pathogenic fungi. J. Nematol. 34, 1-8.

Morikawa, M., Kagihiro, S., Haruki, M., Takano, K., Branda, S., Kolter, R. and Kanaya, S. (2006): Biofilm formation by a Bacillus subtilis strain that produces $\gamma$-polyglutamate. Microbiology 152, 2801-2807. https://doi.org/10.1099/mic.0.29060-0.

Mui-Yun, W. (2003): Fusarium oxysporum f. sp. lycopersici (Sacc.): PP728 Soil-borne Plant Pathogen Class Project. North Carolina State University. 
Ongena, M., Jourdan, E., Adam, A., Paquot, M., Brans, A., Joris, B., Arpigny, J. L. and Thonart, P. (2007): Surfactin and fengycin lipopeptides of Bacillus subtilis as elicitors of induced systemic resistance in plants. Environ. Microbiol. 9, 1084-1090.

Qiao, J., Yu, X., Liang, X., Liu, Y., Borriss, R. and Liu, Y. (2017): Addition of plant-growth-promoting Bacillus subtilis PTS-394 on tomato rhizosphere has no durable impact on composition of root microbiome. BMC Microbiol. 17, 131. https://doi.org/10.1186/s12866-017-1039-x.

Rana, A., Saharan, B., Joshi, M., Prasanna, R., Kumar, K. and Nain, L. (2011): Identification of multi-trait PGPR isolates and evaluating their potential as inoculants for wheat. Ann. Microbiol. 61, 893-900. https://doi. org/10.1007/s13213-011-0211-z.

Raupach, G. S. and Kloepper, J. W. (1998): Mixtures of plant growth-promoting rhizobacteria enhance biological control of multiple cucumber pathogen. Phytopathology 88, 1158-1164. https://doi.org/10.1094/ PHYTO.1998.88.11.1158.

Richardson, A. E., Barea, J. M., McNeill, A. M. and Prigent-Combaret, C. (2009): Acquisition of phosphorus and nitrogen in the rhizosphere and plant growth promotion by microorganisms. Plant Soil 321, 305-339. https://doi.org/10.1007/s11104-009-9895-2.

Riungu, G., Muthomi, J. W., Narla, R. D., Wagacha, J. M. and Gathumbi, J. K. (2008): Management of Fusarium head blight of wheat and deoxynivalenol accumulation using antagonistic microorganisms. Plant Pathol. J. 7, 13-19. http://dx.doi.org/10.3923/ppj.2008.13.19.

Roberts, M. S., Nakamura, L. K. and Cohan, F. M. (1994): Bacillus mojavensis sp. nov., distinguishable from Bacillus subtilis by sexual isolation, divergence in DNA sequence, and differences in fatty acid composition. Int. J. System. Bacteriol., 44, 256-264.

Romero, D., Pérez-García, A., Rivera, M. E., Cazorla, F. M. and de Vicente, A. (2004): Isolation and evaluation of antagonistic bacteria towards the cucurbit powdery mildew fungus Podosphaera fusca. Appl. Microbiol. Biotechnol. 64, 263-269. https://doi.org/10.1007/s00253-003-1439-8.

Shafi, J., Tian, H. and Ji, M. (2017): Bacillus species as versatile weapons for plant pathogens: A review. Biotechnol. Equip. 31, 446-459. https://doi.org/10.1080/13102818.2017.1286950.

Shanmugam, V., Atri, K., Gupta, S., Kanoujia, N. and Singh Naruka, D. (2011): Selection and differentiation of Bacillus spp. Antagonistic to Fusarium oxysporum f. sp. lycopersici and Alternaria solani infecting tomato. Folia Microbiol., 56, 170-177. https://doi.org/10.1007/s12223-011-0031-3.

Sharma, R., Chauhan, A. and Shirkot, C. K. (2015): Characterization of plant growth promoting Bacillus strains and their potential as crop protectants against Phytophthora capsici in tomato. Biol. Agric. Hortic. 31, 230-244. https://doi.org/10.1080/01448765.2015.1009860.

Shoda, M. (2000): Bacterial control of plant diseases. J. Biosci. Bioeng. 89, 515-521. https://doi.org/10.1016/ S1389-1723(00)80049-3.

Stein, T. (2005): Bacillus subtilis antibiotics: structures, syntheses and specific functions. Mol. Microbiol. 56, 845-857. https://doi.org/10.1111/j.1365-2958.2005.04587.x.

Turner, J. T. and Backman, P. A. (1991): Factors relating to peanut yield increases after seed treatment with Bacillus subtilis. Plant Dis. 75, 347-353.

Turner, S., Pryer, K. M., Miao, V. P. W. and Palmer, J. D. (1999): Investigating deep phylogenetic relationships among cyanobacteria and plastids by small subunit rRNA sequence analysis. J. Eukaryot Microbiol. 46, 327-338.

Wang, X., Wang, L., Wang, J., Jin, P., Liu, H. and Zheng, Y. (2014): Bacillus cereus AR156- induced resistance to Colletotrichum acutatum is associated with priming of defense responses in loquat fruit. PLos ONE, 9 (11): e112494. https://doi.org/10.1371/journal.pone.0112494.

Whipps, J. M. (2001): Microbial interactions and biocontrol in the rhizosphere. J. Exp. Bot. 52, 487-512. https:// doi.org/10.1093/jexbot/52.suppl_1.487.

Zhang, S., Raza, W., Yang, X., Hu, J., Huang, Q., Xu, Y., Liu, X., Ran, W. and Shen, Q. (2008): Control of Fusarium wilt disease of cucumber plants with the application of a bioorganic fertilizer. Biol. Fertil. Soils 44, 1073-1080. https://doi.org/10.1007/s00374-008-0296-0. 
